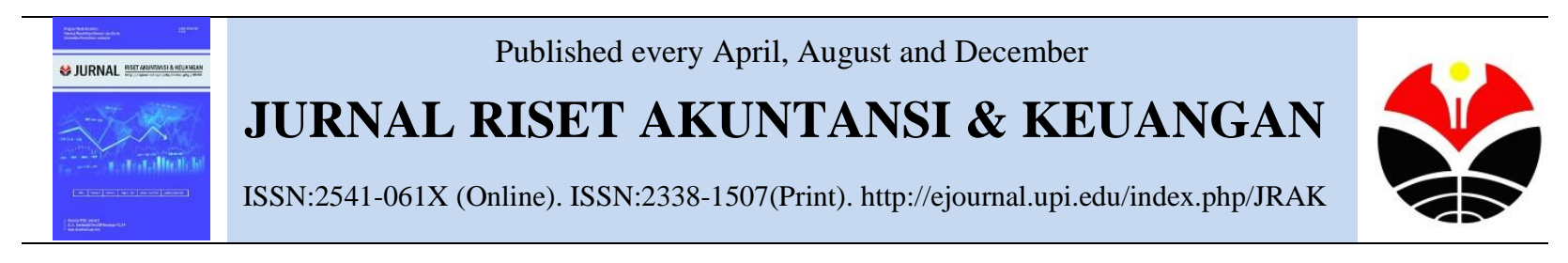

\title{
Pengaruh Likuditas Dan Nilai Tukar Terhadap Harga Saham Setelah Ipo Pada Perusahaan Yang Terdaftar Di Bursa Efek Indonesia Tahun 2009 Sampai Tahun 2014
}

\author{
Taufik Amirudin $W^{1}$, Denny Andriana ${ }^{2}$ \\ Program Studi Akuntansi, FPEB, Universitas Pendidikan Indonesia, Bandung, Indonesia
}

\begin{abstract}
This study aims to determine the effect of corporate liquidity and exchange rate on stock prices after conducting IPO (Initial Public Offering) in Indonesia Stock Exchange. The study was conducted by taking 78 samples of companies whose IPO in 2009-2014. The analytical method used is multiple linear regression that compares the statistical hypothesis with the results. Regression results show the liquidity variables affect the stock price after the IPO with a positive correlation direction. While the variable exchange rate of Rupiah to US Dollar does not affect the stock price after IPO with negative correlation direction. Tests together (simultaneously) show the independent variables of liquidity and exchange rate as a whole affect the dependent variable or stock price after the IPO

Keywords: Liquidity, Exchange Rate, Stock Price

Abstrak. Penelitian ini bertujuan untuk mengetahui pengaruh likuiditas perusahaan dan nilai tukar terhadap harga saham setelah melakukan IPO (Initial Public Offering) di Bursa Efek Indonesia. Penelitian dilakukan dengan mengambil 78 sampel perusahaan yang IPO di tahun 2009-2014. Metode analisis yang digunakan adalah regresi linier berganda yang membandingkan hipotesis statistik dengan hasil. Hasil regresi menunjukan variabel likuiditas berpengaruh terhadap harga saham setelah IPO dengan arah korelasi positif. Sedangkan variabel nilai tukar Rupiah terhadap Dolar AS tidak berpengaruh terhadap harga saham setelah IPO dengan arah korelasi negatif. Uji bersama-sama (secara simultan) menunjukan variabel independen yaitu likuiditas dan nilai tukar secara keseluruhan mempengaruhi variabel dependen atau harga saham setelah IPO

Kata Kunci: Likuiditas, Nilai Tukar, Harga Saham
\end{abstract}

Corresponding author. Email: ${ }^{2}$ denny.andriana@upi.edu

How to cite this article. Andriana, T. A. D. (2016). Pengaruh Likuiditas Dan Nilai Tukar terhadap Harga Saham setelah IPO Pada Perusahaan yang Terdaftar di Bursa Efek Indonesia Tahun 2009 sampai 2014. Jurnal Riset Akuntansi Dan Keuangan. Program Studi Akuntansi. Fakultas Pendidikan Ekonomi Dan Bisnis Universitas Pendidikan Indonesia, 4(1), 949-956. Retrieved from http://ejournal.upi.edu/index.php/JRAK/article/view/7718 History of article. Received: January 2016, Revision: Maret 2016, Published: April 2016

Online ISSN: 2541-061X. Print ISSN: 2338-1507. DOI : 10.17509/jrak.v4i1.7718

Copyright@2016. Jurnal Riset Akuntansi dan Keuangan Program Studi Akuntansi FPEB UPI 


\section{PENDAHULUAN}

Pembiayaan dari sebuah perusahaan diperoleh dari dua sumber yaitu dari dalam perusahaan (internal) berupa laba dan dari luar perusahaan (eksternal) berupa hutang dan penerbitan sekuritas oleh perusahaan di pasar modal. "Pada saat terjadi krisis ekonomi global di tahun 2008, negara adidaya Amerika Serikat mengalami resesi yang serius, sehingga terjadi perlambatan pertumbuhan ekonomi yang selanjutnya menggerus daya beli masyarakat Amerika. Hal ini sangat mempengaruhi negara-negara lain karena Amerika Serikat merupakan pangsa pasar yang besar bagi negara-negara lain termasuk Indonesia. Inilah yang menyebabkan terjadinya defisit Neraca Pembayaran Indonesia (NPI). Bank Indonesia memperkirakan secara keseluruhan NPI mencatatkan defisit sebesar US\$2,2 miliar pada tahun 2008." (Ibnu Purma dkk : 2009) Penurunan daya beli masyarakat di Amerika menyebabkan penurunan permintaan impor dari Indonesia. Dengan demikian ekspor Indonesia pun menurun. Penarikan modal asing secara besar juga mendorong terus terjadinya defisit terhadap NPI pada tahun 2008. Pada masa krisis global beberapa tahun lalu, supply Dolar di Indonesia menurun. Padahal Demand Dolar di dalam negeri mengalami kenaikan yang terus merenerus dari tahun ke tahun. Data dari Kementerian Keuangan dan Bank Indonesia satu tahun setelah krisis di tahun 2008 menunjukan jumlah hutang swasta sebesar 73.606 juta USD. Dan terus meningkat pada tahun 2010 di angka 83.789 juta USD. (Kementerian Keuangan dan Bank Indonesia : 2015) Hal ini ini mengakibatkan adanya keketatan likuiditas global dan menurunkan nilai tukar rupiah terhadap mata uang asing atau khususnya dolar.

Pada saat krisis ekonomi kesehatan perusahaan menjadi faktor penting dalam proses penilaian sebuah perusahaan. Keputusan untuk berinvestasi pada perusahaan IPO cenderung untuk mendapatkan keuntungan yang lebih besar, oleh karena itu faktor kehati-hatian dalam melihat kondisi financial suatu perusahaan haruslah diperhatikan dengan seksama. Salah satu faktor yang harus diperhatikan adalah kondisi likuiditas dari keuangan suatu perusahaan untuk menghindari dari tuntutan pailit yang akan merugikan bagi para pemilik modal. Kondisi iklim investasi pada pasar modal sendiri sedikit banyaknya dipengaruhi oleh kondisi ekonomi makro dari suatu Negara. Nilai tukar rupiah yang berlaku di Indonesia menjadi salah satu faktor dari ekonomi makro yang berhubungan dengan likuiditas karena perusahaan yang memiliki hutang luar negeri harus menyediakan pembayaran dalam bentuk mata uang asing yang sesuai dengan pinjamannya.

\section{KAJIAN LITERATUR}

Kieso dan Weygandt dalam Intermediate Accounting (2010) mendefinisikan laporan keuangan sebagai berikut :

"Financial statements are the principal means through which financial information is communicated to those outside an enterprise. These statement provide the company's history quantified in money terms."

"Laporan keuangan sangat diperlukan oleh manajer untuk meningkatkan kinerja perusahaan, bagi investor laporan keuangan berguna untuk mengevaluasi kemungkinan dibayarnya pinjaman dan bagi pemegang saham berguna untuk meramalkan laba, dividen, dan harga saham." (Moeljadi, 2006:67).

Laporan keuangan bagi sebuah perusahaan merupakan prestasi dari baik dan buruknya kinerja perusahaan. Laporan keuangan menjadi hal yang akan dipertimbangkan oleh banyak pihak dalam proses pengambilan keputusan.

\section{Rasio Keuangan}

Kasmir (2008:104) Menyatakan bahwa, "Rasio keuangan merupakan kegiatan membandingkan angka-angka yang ada dalam laporan keuangan dengan cara membagi satu angka dengan angka lainnya. Rasio keuangan digunakan untuk mengevaluasi kondisi keuangan dan kinerja perusahaan. Dari hasil 
rasio keuangan ini akan terlihat kondisi kesehatan perusahaan yang bersangkutan."

Rasio keuangan adalah angka yang diperoleh dari hasil perbandingan dari satu pos laporan keuangan dengan pos lainnya yang merupakan hubungan yang relevan dan signifikan. Menurut Pike (1983) rasio keuangan merupakan salah satu faktor paling dominan bagi seseorang untuk melakukan investasi saham pada perusahaan yang melakukan initial public offering (IPO).

\section{Rasio Likuiditas}

Pengertian Likuiditas menurut Brigham dan Houston (2010 :134), yaitu :“Aset likuid merupakan asset yang diperdagangkan di pasar aktif sehingga dapat dikonversi dengan cepat menjadi kas pada harga pasar yang berlaku, sedangkan posisi likuiditas suatu perusahaan berkaitan dengan pertanyaan, apakah perusahaan mampu melunasi utangnya ketikan utang tersebut jatuh tempo di tahun berikutnya."Menurut Harahap (2007:301) definisi rasio likuiditas adalah "Rasio yang digunakan untuk menggambarkan kemampuan perusahaan untuk menyelesaikan kewajiban jangka pendeknya."

Berdasarkan beberapa definisi likuditas menurut ahli dapat disimpulkan bahwa rasio likuiditas adalah rasio yang mengukur kemampuan perusahaan untuk menyelesaikan hutang jangka pendeknya.

\section{Nilai Tukar}

Abimanyu (dalam Sudi 2010 : 8) "nilai tukar atau kurs (foreign exchange rate) adalah harga mata uang suatu negara relatif terhadap mata uang negara lain." Karena nilai tukar ini mencakup dua mata uang, maka titik keseimbangannya ditentukan oleh sisi penawaran dan permintaan dari kedua mata uang tersebut.

Pengertian lain yang di ungkapkan Triyono (Triyono, 2008 : 2) "Kurs (Excange Rate) adalah pertukaran antara dua mata uang yang berbeda, merupakan perbandingan nilai atau harga antara kedua mata uang tersebut."

Dapat disimpulkan dari beberapa definisi diatas bahwa nilai tukar adalah sejumlah uang dari suatu mata uang tertentu yang dapat dipertukarkan dengan satu unit mata uang negara lain. Tandelilin (2000) menyatakan bahwa faktor-faktor ekonomi makro secara empirik telah terbukti mempunyai pengaruh terhadap kondisi pasar modal di beberapa negara. Faktor-faktor tersebut yaitu laju pertumbuhan inflasi, tingkat suku bunga dan nilai tukar mata uang (exchange rate).

\section{Penawaran Umum Perdana (Initial Public Overing)}

Kegiatan perusahaan dengan cara menjual sahamnya pada public (go public) melalui pasar pasar modal untuk pertama kalinya adalah Penawaran Umum Perdana atau Initial Public Offering (IPO). UndangUndang Republik Indonesia No. 8 Tahun 1995 tentang Pasar Modal, Bab I butir 15 mendefinisikan bahwa : "Penawaran umum adalah kegiatan penawaran efek yang dilakukan oleh emiten untuk menjual efek kepada masyarakat berdasarkan tata cara yang diatur dalam undang-undang ini dan peraturan pelaksanaannya." "Go Public merupakan saraana pendanaan usaha melalui pasar modal yaitu dapat berupa penawaran umum saham maupun penawaran obligasi. Masing-masing pilihan memiliki keuntungan dan karakteristik tersendiri yang seyogyanya disesuaikan dengan kebutuhan dan kondisi perusahaan". (Darmadji dan Fakhruddin, 2012 : 57)

Penawaran umum adalah kegiatan penawaran efek yang dilakukan oleh emiten untuk menjual efek kepada masyarakat berdasarkan tata cara yang diatur dalam undang-undang dan peraturan pelaksanaannya. Hasil penjualan saham tersebut masuk sebagai modal perusahaan.

\section{METODOLOGI PENELITIAN}

\section{Ruang Lingkup Penelitian}

Penelitian ini memiliki batasan pengambilan data dalam kurun waktu selama 6 tahun yaitu sejak tahun 2009-2014.

\section{Metode Penentuan Sampel}


Pengertian sampel menurut Sugiyono (2010:81) adalah bagian dari jumlah dan karakteristik yang dimiliki oleh populasi tersebut. Dengan menggunakan metode Purposive Sampling yaitu teknik pengambilan sampel sumber data dengan pertimbangan tertentu Sugiyono (2010:218). Dengan kriteria yang digunakan dalam penelitian ini adalah sebagai berikut., 1). Perusahaan yang melakukan Initial Public Overing (IPO) pada tahun 2009-2014., 2.) Perusahaan masih aktif dan terdaftar di BEI sampai 2014., 3).,Melakukan Initial Public Overing (IPO) pada hari senin-rabu.

Dengan populasi dalam penelitian ini adalah semua perusahaan yang melakukan IPO di BEI pada periode 2009 sampai 2014 sebanyak 137 perusahaan. Untuk sampel yang memenuhi kriteria dalam pemilihan sampel dengan menggunakan metode Purposive Sampling seperti disebutkan di atas sebanyak 78 perusahaan.

\section{Metode Analisis}

Metode analisis data yang digunakan dalam penelitian ini, adalah sebagai berikut:

\section{Uji Statistik Deskriptif}

Statistik deskriptif merupakan trasformasi data penelitian dalam bentuk tabulasi (ringkasan, pengaturan, atau penyusunan data dalam bentuk tabel numerik dan grafik) sehingga mudah dipahami dan diinterpretasikan.

\section{Uji Asumsi Klasik}

\section{Uji Linearitas}

Uji linearitas bertujuan untuk mengetahui apakah dua variabel mempunyai hubungan yang linear atau tidak secara signifikan.

\section{Uji Normalitas}

Uji normalitas bertujuan untuk menguji apakah dalam model regresi, variabel dependen dan variabel independen mempunyai distribusi data normal atau tidak dengan menggunakan Normal P-Plot.

\section{Uji Multikoliniearitas}

Uji multikoliniearitas bertujuan untuk menguji apakah dalam model regresi ditemukan adanya korelasi antar variabel independen (Ghozali, 2005:91).

\section{Uji Autokorelasi}

Uji autokorelasi bertujuan menguji apakah dalam sebuah model regresi linear ada korelasi antara kesalahan penggangu pada periode $\mathrm{t}$ dengan kesalahan pada periode $\mathrm{t}-1$ (sebelumnya).

\section{Uji Heteroskedastitas}

Uji heteroskedstisitas bertujuan menguji apakah dalam model regresi terjadi ketidaksamaan variance dari residual atau pengamatan ke pengamatan yang lain dengan menggunakan grafik Scatteplot. Model regresi yang baik adalah tidak terjadi heteroskedastisitas (Ghozali, 2005:105).

\section{Uji Regresi Berganda}

Uji Regresi berganda ini bertujuan untuk memprediksi besarnya keterkaitan dengan menggunakan data variabel bebas yang sudah diketahui besarnya (Santoso 2002: 163).

\section{Uji Hipotesis}

\section{Analisis Korelasi}

Untuk menguji hipotesis digunakan analisis korelasi. Menurut Suharyadi (2009:158), analisis korelasi adalah suatu teknik statistika yang digunakan untuk mengukur keeratan hubungan atau korelasi antara dua variabel.

Uji Koefisien Determinasi $\left(R^{2}\right)$

Nilai $R^{2}$ digunakan untuk mengukur seberapa jauh kemampuan model dalam menerangkan variasi variabel dependen.

\section{Uji Statistik t}

Uji statistik $\mathrm{t}$ pada dasarnya menunjukkan seberapa jauh pengaruh satu variabel penjelas/independen secara individual dalam menerangkan variasi variabel dependen.

\section{Uji Regresi Simultan (Uji Statistik F)}

Uji statistik F dilakukan dengan tujuan untuk menguji apakah keseluruhan variabel independen mempunyai pengaruh secara bersama-sama terhadap satu variabel dependen.

\section{HASIL DAN PEMBAHASAN}

\section{Uji Asumsi Klasik}

Berdasarkan uji linearitas dapat diketahui bahwa nilai Sig. linearity untuk 
likuiditas adalah sebesar 0.000 lebih kecil dari 0.05 dan nilai Sig. deviation from linearity adalah sebesar 0.621 lebih besar dari 0.05, sehingga dapat disimpulkan bahwa variabel likuiditas dengan harga saham mempunyai hubungan yang linear dan signifikan. Sedangkan nilai Sig. linearity untuk nilai tukar adalah sebesar 0.000 lebih kecil dari 0.05 dan nilai Sig. deviation from linearity adalah sebesar 0.936 lebih besar dari 0.05 , sehingga dapat disimpulkan bahwa variabel nilai tukar dengan harga saham mempunyai hubungan yang linear dan signifikan.

Berdasarkan hasil uji normalitas yang bertujuan untuk menguji apakah dalam model regresi, variabel dependen dan variabel independen mempunyai distribusi data normal atau tidak dengan menggunakan Normal PPlot

\section{Normal P-P Plot of Regression Standardized} Residual

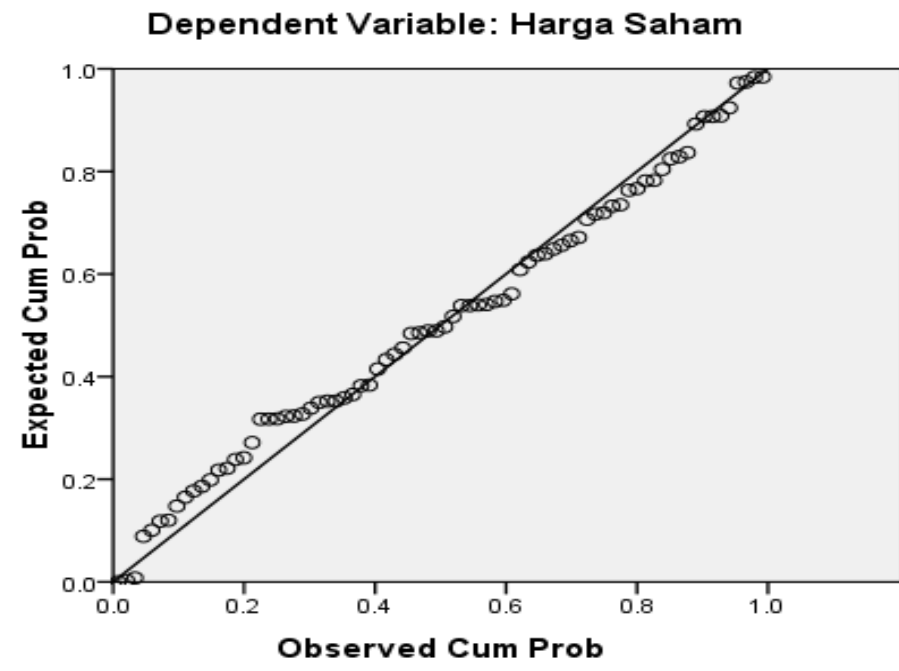

Dari gambar garfik di atas dapat diketahui bahwa titik-titik menyebar sekitar garis dan mengikuti garis diagonal makan nilai residual tersebut telah normal

Pada hasil uji multikolinearitas menunjukkan bahwa variabel likuiditas dan nilai tukar semuanya tidak terjadi multikolinearitas, karena nilai tolerance berada di atas 0.10 yaitu 0.837 dan nilai VIF berada di bawah 10 yaitu 1.194 .

Pengujian Autokorelasi dengan Durbin-Watson menunjukkan nilai DW sebesar 1.171. Menurut Ghozali (2005:96). bila nilai angka DW di antara -2 sampai +2 , berarti tidak ada autokorelasi. 


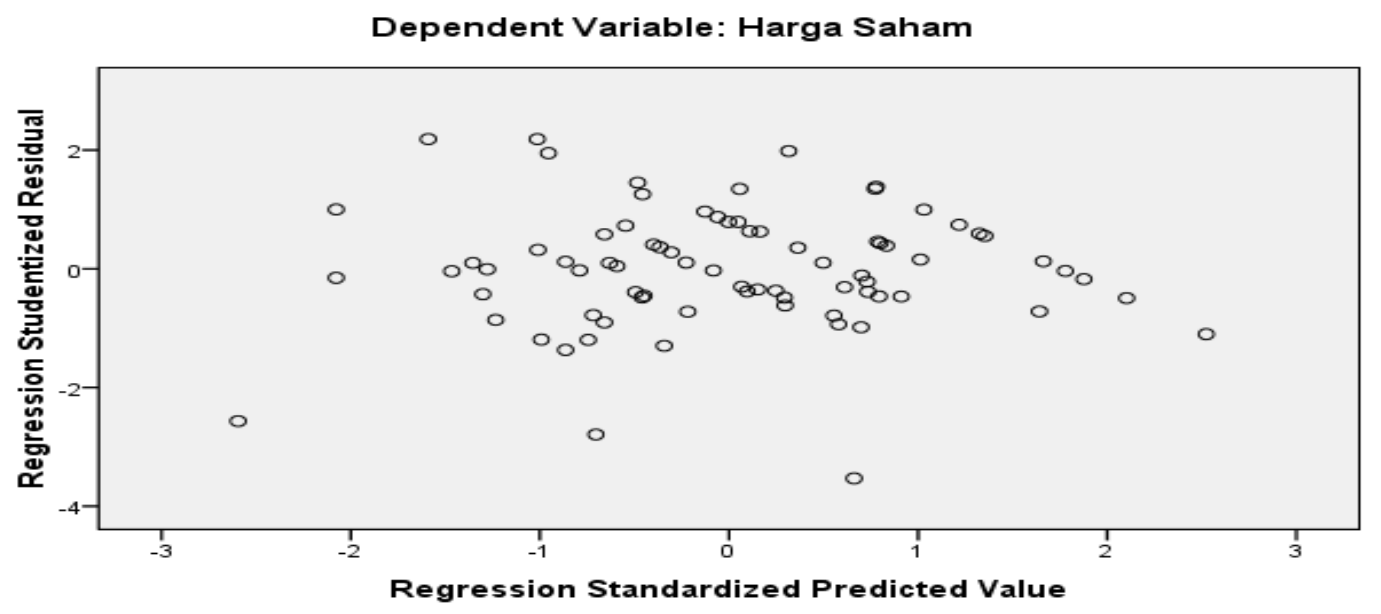

Berdasarkan diagram pencar di atas, maka dapat dilihat bahwa penyebaran residual bersifat homogen. Hal tersebut dapat dilihat dari plot yang tidak menyebar dan tidak membentuk suatu pola tertentu. Dengan hasil demikian dapat disimpulkan bahwa tidak terjadi gejala heteroskedastisitas.

\section{Analisis Regresi Berganda}

Berdasarkan hasil regresi linier berganda pada pengujian ini dapat dilihat hubungan antara likuiditas dan nili tukar terhadap harga saham setelah IPO menghasilkan persamaan sebagai berikut :

$Y=4.496+0.251 X_{1}-0.057 X_{2}+\varepsilon$

Persamaan dari model regresi di atas dapat dijelaskan sebagai berikut: Konstanta sebesar 4.496 menyatakan bahwa jika tidak ada rasio likuiditas dan nilai tukar maka harga saham setelah IPO adalah sebesar 4.496. Koefisien regresi $\mathrm{X}_{1}$ sebesar 0.251 menyatakan bahwa setiap peningkatan rasio likuiditas sebesar 1 $\%$ maka akan menyebabkan kenaikan harga saham setelah IPO sebesar 0.251, dengan catatan variabel lain dianggap konstan. $\begin{array}{llll}\text { Koefisien regresi } \mathrm{X}_{2} & \text { sebesar } & -0.057\end{array}$ menyatakan bahwa setiap penurunan nilai tukar dolar sebesar $1 \%$ maka akan menyebabkan kenaikan harga saham setelah IPO sebesar 0.057, dengan catatan variabel lain dianggap konstan.

\section{Analisis Koefisien Korelasi}

Berdasarkan perhitungan didapatkan hasil koefisien korelasi sebesar 0.809 yang mempunyai arti bahwa terdapat hubungan sangat kuat antara rasio likuiditas dan nilai tukar dengan harga saham perusahaan setelah IPO.

\section{Koefisien Determinasi}

Koefisien determinasi dihitung dengan mengkuadratkan koefisien korelasi yang telah ditemukan dan selanjutnya dikalikan dengan $100 \%$. KD $=(0.809)^{2} \times 10 \%$

\section{Pengujian Hipotesis}

\section{Pengujian Hipotesis Secara Parsial}

Koefisien beta pertama 0.696, diperoleh nilai $\mathrm{t}_{\text {hitung }}$ sebesar 9.383 dengan mengambil taraf signifikan $\alpha$ sebesar 5\%, maka nilai $\mathrm{t}_{\text {tabel }}$ atau $\mathrm{t}_{0,05.75}=1.991$. Sehingga, dikarenakan $\mathrm{t}_{\text {hitung }}=$ 9.383 lebih besar dari $t_{\text {tabel }}=1.991$, maka menolak Ho atau dengan kata lain rasio likuiditas $\left(\mathrm{X}_{1}\right)$ berpengaruh terhadap harga saham perusahaan setelah IPO. Hasil t positif menunjukan bahwa likuiditas $\left(\mathrm{X}_{1}\right)$ mempunyai hubungan yang searah dengan harga saham setelah IPO (Y).

Koefisien beta kedua -0.218 , diperoleh nilai $\mathrm{t}_{\text {hitung }}$ sebesar -1.837 dengan mengambil taraf signifikan $\alpha$ sebesar 5\%, maka nilai t tabel atau $\mathrm{t}_{0,05.75}=\quad$-1.991. Sehingga, dikarenakan $\mathrm{t}_{\text {hitung }}=-1.837$ lebih kecil dari $\mathrm{t}_{\text {tabel }}=-1.991$, maka menerima Ho atau dengan 
kata nilai tukar $\left(\mathrm{X}_{2}\right)$ tidak berpengaruh terhadap harga saham setelah IPO (Y). Hasil t negatif menunjukan bahwa nilai tukar $\left(\mathrm{X}_{2}\right)$ mempunyai hubungan yang berlawanan arah dengan harga saham setelah IPO (Y).

\section{Pengujian Hipotesis Secara Simultan}

Berdasarkan perhitungan diperoleh nilai $F_{\text {hitung }} 71.006$ lebih besar dari $F_{\text {tabel }} 3.119$, dan sig F sebesar 0.000, maka Ho ditolak. Artinya dapat disimpulkan bahwa terdapat pengaruh secara linier antara rasio likuiditas dan nilai tukar terhadap harga saham perusahaan setelah IPO, atau dapat diartikan terdapat pengaruh secara bersama-sama (simultan) ke dua sub variabel yaitu rasio likuiditas dan nilai tukar terhadap harga saham perusahaan setelah IPO

\section{SIMPULAN}

Berdasarkan hasil pengujian linier berganda mengindikasikan bahwa hubungan variabel likuiditas memiliki pengaruh positif terhadap harga saham setelah IPO. Sedangkan nilai tukar memiliki pengaruh negative terhadap harga saham setelah IPO. Hal tersebut mengindikasikan bahwa kenaikan tingkat likuiditas akan meningkatkan Harga saham setelah IPO. Serta apabila terjadi kenaikan nilai tukar rupiah terhadap dolar AS maka akan mengakibatkan turunnya harga saham.

Berdasarkan hasil pengujian secara parsial mengindikasikan bahwa hanya variabel likuiditas yang memiliki pengaruh sementara nilai tukar tidak memiliki pengaruh.

Berdasarkan pengujian secara bersamasama (simultan) mengindikasikan bahwa keseluruhan variabel independen memberikan pengaruh terhadap variabel dependen serta nilai signifikan yang dihasilkan pada uji $\mathrm{F}$ mengindikasikan hasil penelitian ini memperoleh pengaruh dari variabel bebas terhadap variabel terikat.

\section{DAFTAR PUSTAKA}

Abimayu, Yoopi. (2004) Memahami Kurs Valuta Asing. FE-UI, Jakarta.
Alwi, Iskandar Z. (2003). Pasar Modal Teori dan Aplikasi. (Edisi Pertama). Jakarta : Penerbit Yayasan Pancur Siwah.

Ang, Robert. (1997). Buku Pintar Pasar Modal Indonesia. Jakarta : Media Soft Indonesia

Anoraga, P. dan Pakarti. (2006). Pengantar Pasar Modal. (Cetakan Pertama). Jakarta : PT. Rineka Cipta.

Asri Sitompul. (2000). Penawaran Umum dan Permasalahannya. Bandung : Citra Aditya Bakti.

Brigham F. Eugene dan Houston, Joel. (2010). Dasar - Dasar Manajemen Keuangan : Assetials of Financial Management. Jakarta: Penerbit Salemba Empat.

Cooper, Donald R. dan Pamela S. Schindler. (2006). Metode riset bisnis, vol. 1, edisi 9 (Business research methods, 9th edition); Budijanto, Didik Djunaedi, Damos Sihombing, penerjemah. Jakarta: Media Global Edukasi.

Darmadji, Tjiptono dan M. Fakhruddin, Hendy. (2012). Pasar Modal Di Indonesia. Jakarta : Salemba Empat.

Darmadji, Tjiptono dan M. Fakhruddin, Hendy. (2001). Pasar Modal Di Indonesia. Jakarta : Salemba Empat

Ghozali, Imam dan Mansur Al, M. (2002) Analisis Faktor-Faktor yang Mempengaruhi tingkat Underpricing di Bursa Efek Jakarta, Jurnal Bisnis dan Akuntansi, Vol.4. No.1, April 2002.

Ghozali, Imam. (2005). Aplikasi Analisis Multivariate dengan program SPSS, Semarang : BP UNDIP.

Given, Lisa M. (editor). (2008). The Sage encyclopedia of qualitative research methods. Thousand Oaks: Sage.

Gujarati. (2005). SPSS Versi 16 Mengolah Data Statistik Secara Profesional. Jakarta: Gramedia Pustaka Utama.

Harahap, Sofyan Syafri. (2007). Analisis Kritis Atas Laporan Keuangan. Jakarta : Rajawali Pers. 
Husnan, S. (2005). Dasar-dasar Teori Portofolio dan Analisis Sekuritas. Yogyakarta : UPP AMP YKPN

Ibnu Purma, Hamidi dan Prima. (2009). Perekonomian Indonesia Tahun 2008 Tengah Krisis Keuangan Global. [Online]:

http://www.setneg.go.id/index.php?opt ion=com_content $\&$ task=view $\& \mathrm{id}=369$ 8

Kasmir. (2008). Analisis Laporan Keuangan. Jakarta : Rajawali Pers.

Kementerian Keuangan dan Bank Indonesia. (2015). Statistik Utang Luar Negeri Indonesia, vol. VI. Jakarta : Publikasi Bersama Kemenkeu dan BI

Keown, Martin, Petty, Scoot Jr. (2008). Manajemen Keuangan: PrinsipPrinsip dan Aplikasi. (Edisi Kesembilan), Jilid 1, Indeks.

Keputusan Menteri Keuangan RI No. 859/KMK.01/1987 tentang Emisi Efek Melalui Bursa

Kieso, D. E., Weygandt, J. J., \& Warfield, T. D. (2010). Intermediate Accounting: IFRS Edition Volume 1. USA: John Wiley \& Sons.

Martono dan Agus Harjito. (2003). Manajemen Keuangan. Yogyakarta: Ekonisia.

Moeljadi. (2006). Manajemen Keuangan Pendekatan Kuantitatif dan Kualitatif. Jilid 1. Malang : Bayumedia Publishing.

Moeljadi. (2006). Manajemen Keuangan: Pendekatan Kuantitatif dan Kuaitatif. Malang : Bayumedia.

Narimawati, U. (2008). Metodologi Penelitian Kualitatif dan Kuantitatif, Teori dan Aplikasi. Bandung: Agung Media

Pike, H, William. (1983). Why Stock Go Up (and Down), A Guide to Sound Investing. Illonois : Dow Jones-Irwin, Honewood.

Prastowo, Dwi dan Juliaty Rifka. (2002). Analisis Laporan Keuangan Konsep dan Aplikasi. (Edisi ke-2). Yogyakarta : UPP AMP YKPN.

Republik Indonesia. (1995). Undang-undang No. 8 Tahun 1995 Tentang Pasar
Modal. Lembaran Negara RI Tahun 1995 No. 64. Jakarta : Sekretariat Negara.

Riyanto, Bambang (2001). Dasar-dasar Pembelajaran Perusahaan. (Edisi 4). Yogyakarta : BPFE

Samsul, M. (2006). Pasar Modal dan Manajemen Portofolio. Jakarta : Erlangga

Sitinjak, E.L.M. dan Widuri Kurniasari. (2003). Indikator-indikator Pasar Saham dan Pasar Uang yang Saling Berkaitan ditinjau dari Pasar Saham sedang Bullish dan Bearish. Jurnal Riset Ekonomi dan Bisnis. Vol.3, No.3.

Sudana, I. M., "Manajemen Keuangan Teori dan Praktek", Airlangga University Press, Surabaya, 2009.

Sudi, B. (2010). Peranan Faktor Fundamental dalam Nilai Tukar Rupiah Terhadap Dolar Amerika Januari 2000 Desember 2009. (Tesis). Sekolah Pascasarjana, Universitas Indonesia, Jakarta.

Sugiyono (2004). Metode Penelitian Bisnis. Bandung: Alphabeta

Sugiyono (2010). Metode penelitian Kuantitatif \& RND. Bandung : Alfabeta

Sugiyono (2011). Statistik untuk Penelitian. Bandung : Alphabeta.

Tandelilin, Eduardus. (2000) Pasar modal Indonesia: Problem dan Prospek. Wahana, volume 3, No.2

Triyono. (2008). Analisis Perubahan Kurs Rupiah Terhadap Dollar Amerika. Jurnal Ekonomi Pembangunan, Vol. 9, No. 2, Desember 2008, hal. 156 167.

Weston, J. Fred dan Thomas E. Copeland. (1996) “Manajemen Keuangan”, (Jilid Dua), Terjemahan oleh Jaka Wasana dan Kibrandoko, 2000, Jakarta : Bina Rupa Aksara.

Widoatmodjo, S. (2005) Cara Sehat Investasi di Pasar Modal, Jakarta : PT Elex Media Komputindo. 